\title{
Lactoferrin Measurement
}

National Cancer Institute

\section{Source}

National Cancer Institute. Lactoferrin Measurement. NCI Thesaurus. Code C82021.

The determination of the amount of lactoferrin present in a sample. 